\author{
Send your letters to the editor, British Dental \\ Journal, 64 Wimpole Street, London W1G 8YS \\ E-mailbdj@bda.org \\ Priority will be given to letters less than 500 \\ words long. Authors must sign the letter \\ which may be edited for reasons of space.
}

\section{Misleading news}

Sir, it is misleading to suggest, as in your news article Dentists gain incorporation status (BDJ 2006; 201: 191), that the professional indemnity of dentists who set up as a limited company or limited liability partnership will no longer be valid. In fact, the Dental Defence Union (DDU) would advise any dental member in this position to retain his or her DDU membership, as s/he will be able to seek indemnity under our insurance policy should a clinical negligence claim be directed against him or her personally in respect of clinical services $s /$ he has provided, whether s/he is an employee or director/partner of the corporate entity. In addition, if the corporate entity was sued in respect of his or her clinical negligence, s/he would also be able to call upon us for assistance if $\mathrm{s} /$ he was named as a third party.

It is, however, likely that those establishing a limited company or limited liability partnership will wish to make additional indemnity arrangements in respect of any liabilities for clinical negligence which may fall to the company or partnership itself, and we encourage dental professionals who are considering such schemes to contact us to discuss their plans on 02072021570 or at salesq@the-mdu.com.

R. Hoppenbrouwers

Head of the DDU

doi: 10.1038/sj.bdj.4814162

\section{AED training for dentists}

Sir, we are very supportive of the new guidance issued by the Resuscitation Council (UK), Medical emergencies and resuscitation - Standards for clinical practice and training for dental practitioners and dental care professionals. The question was raised by P. Coulthard and D. Craig in their letter (BDJ 2006; 201: 189) as to who is to provide the recommended training in the use of Automated External Defibrillators (AEDs).

In 1999 we invited a team of colleagues, including RTOs, paramedics and anaesthetists to help us to design a medical emergencies course specifically tailored to dentists. The course runs over two full days (at a weekend for convenience) and includes training on the use of AEDs. The course has proved very popular and several of the practitioners who have participated have purchased AEDs for their practices. We also run a full week medical emergencies course for our undergraduate students and this also involves training in the use of AEDs. Within the hospital we provide training for our DCPs and staff training sessions for medical emergencies, again including the use of defibrillators. The staff who teach on these courses are certificated ALS instructors to ensure the training is both safe and standardised. We appreciate that there will be an increased demand for this type of training but there are several avenues that can be explored to provide it. Details of the DALS (Dental Advanced Life Support) course can be found in the Dental section of the Mersey Deanery website: www.merseydeanery.ac.uk.

\section{C. Balmer \\ L. P. Longman \\ Liverpool}

doi: $10.1038 /$ sj.bdj.4814163

\section{Out of the mouths of clinicians}

Sir, 'Signum scientis est posse docere.' This Latin dictum translates, 'The touchstone of knowledge is the ability to teach'. Henry Adams said: 'A teacher affects eternity; he can never tell where his influence stops.' Why then are dental and medical educators feeling disillusioned, and why does the regard for teaching seem to be a lost convention? Even among clinicians there seems to be a lack of regard for educators. Many clinicians will attempt to impress those more junior with the quote, 'He who can, does. He who cannot, teaches.' The implication is that teaching is a simple task and that anyone with a dental or medical qualification is automatically a teacher. However, this assumption is likely to be incorrect. ${ }^{1}$

The responsibilities of educators in dentistry are far-reaching. From undergraduate through to pre-consultant level, educators need to teach their

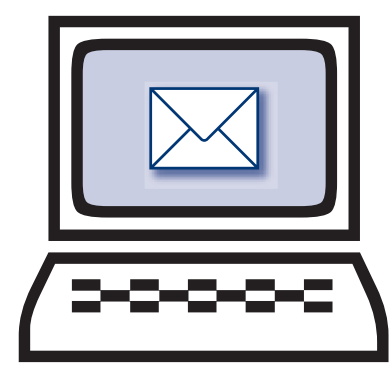

juniors the application of theoretical knowledge to clinical practice, the development of thought processes capable of modifying original guiding concepts in the light of ever-changing evidence and the maintenance of composure and professionalism under the pressure of the most difficult clinical and bureaucratic conditions.

The most important common denominator for every great educator is undoubtedly enthusiasm in his or her subject. However, is enthusiasm enough? Clinicians will all be involved in teaching juniors at some point in their career. The word 'doctor' in fact comes from the Latin word for 'teacher'. The 'see one, do one, teach one' model of education is as old as medicine. However, teaching requires not only knowledge about the learning process, but also an appreciation of students' goals, motivations, and experiences, as well as a learning environment suitable to the student. ${ }^{2}$ Medicine has not appreciated the 'science' of teaching, and the concept that different people learn in different ways. Formal 'clinician as teacher' courses can be a vital step forward in training clinicians to become better teachers.

Educators are still financially supported mainly by their primary role of either clinician or researcher. It is said that, 'Education costs money, but then so does ignorance.' Maintaining high quality medical and dental educators may cost money, but poorly trained clinicians will cost a lot more in the long term!

Finally, is there any truth behind the often-quoted expression, 'He who can, does. He who cannot, teaches'? The phrase originates from the Irish playwright George Bernard Shaw (1903). The phrase is, however, used out of context, as Shaw was referring to revolutionaries, not teachers. ${ }^{3}$ Perhaps the next time one hears the phrase used out of context, one may respond with the quote, 'Those who can, do; those who understand, teach.' This is from Aristotle, and he was referring to teachers!
F. B. Nain
D. S. Gill
London 
1. Pasquale S J, Pugnaire M P. Preparing medical students to teach. Acad Med 2002; 77: 1175-1176.

2. Arky R A. Shattuck Lecture. The family business - to educate. NEng/J Med 2006; 354: 1922-1926.

3. Naini F B. So, those who can't do it, teach it? Br Med J 2006; 332: 219

doi: 10.1038/sj.bdj.4814164

\section{Funding education}

Sir, I note with interest the article in your journal Dental schools need more funding (BDJ 2006; 201: 192). The programme of visits of dental schools referred to in the article was carried out between autumn 2003 and June 2005.

In July 2004, following on from the publication of the Review of the Primary Care Dental Workforce, the Department of Health announced a major expansion of dental education supported by a multimillion pound investment programme. The programme included $£ 80$ million capital funding to the dental schools in England to enable them to modernise, update and improve their estates and equipment in order to improve both the services offered to patients and the environment in which undergraduates are trained. The Department, working with the Department for Education and Skills, is also providing extra revenue funding to cover the costs of training the increased undergraduate numbers. By 2010/11 when numbers of students will have increased to over 4,000 - a $25 \%$ increase over the 2004 baseline - revenue expenditure on undergraduate dental training will have increased by $£ 29$ million per year.

This major expansion of dental undergraduate training coupled with the concurrent expansion in the training of dental therapists offers concrete evidence of the Government's commitment to providing the investment required to modernise dental education.

\section{B. Cockcroft}

Chief Dental Officer - England

doi: $10.1038 /$ sj.bdj.4814165

\section{Tooth candy}

Sir, my receptionist was shocked to see this item on sale (Figs 1-2). She purchased it and brought it to my attention. It is a toothbrush made out of candy! The body and handle are made of a hard truly indigestible plastic. The oversized bristles are made of a very sticky hard gum with a green dye to catch the eye. I did not dare to taste it but I am sure that the sweetness of the confectionery would be more than offset by the bitter taste in my mouth resulting from the irony of the situation. It is appalling that the dental health message has been so badly hijacked and corrupted by those responsible. Should the destructive nature of this item fail to

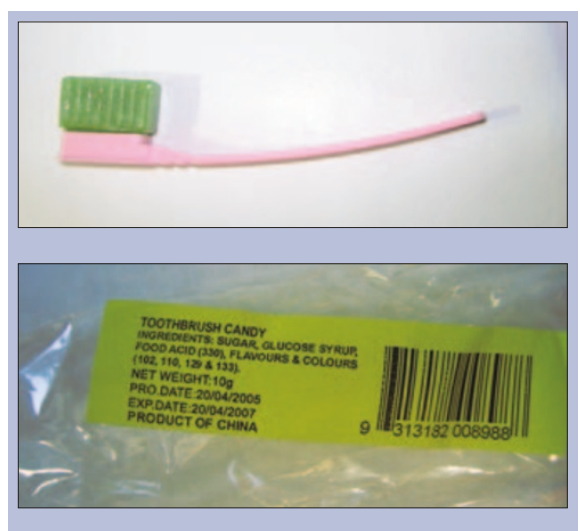

Figs 1-2

satisfy the mavericks behind this product it is supplemented with a plethora of additives adding a soupcon of diseases to the well established foundation of caries in the victims' mouths. I hope that you will agree to publish this letter as a warning to the profession about this hazard.

\section{R. A. Raeburn}

By email

doi: 10.1038/sj.bdj.4814166

\section{Reaction to cinnamon}

Sir, Mr Littler (BDJ 2006; 201: 321)

comments on the association of

cinnamaldehyde with stomatitis. Cinnamon has indeed been implicated in some cases of orofacial granulomatosis ${ }^{1}$ and a range of other oral mucosal reactions, ${ }^{2-4}$ including when incorporated in dentifrices. ${ }^{3}$ Many contact reactions affect the gingivae. ${ }^{5}$ Cinnamon chewing gum has been implicated in occasional cases of burning sensations, red or white lesions - typically on the tongue or buccal mucosae ${ }^{6}-$ and has even been implicated in rare cases of leukoplakia ${ }^{7}$ and carcinoma. ${ }^{8}$

\section{Scully CBE \\ By email}

1. White A, Nunes $C$, Escudier M et al. Improvement in orofacial granulomatosis on a cinnamon- and benzoate-free diet. Inflamm Bowel Dis 2006: 12: 508-514.

2. Miller R L, Gould A R, Bernstein M L. Cinnamoninduced stomatitis venenata, clinical and characteristic histopathologic features. Oral Surg Oral Med Oral Pathol 1992; 73: 708-716.

3. Lamey PJ, Lewis M A, Rees T D etal. Sensitivity reaction to the cinnamonaldehyde component of toothpaste. BrDent J 1990; 168: 115-118.

4. Allen $C M$, Blozis $\mathrm{G} \mathrm{G}$. Oral mucosal reactions to cinnamon-flavored chewing gum. J Am Dent Assoc 1988; 116: 664-667.

5. Endo H, Rees T D. Clinical features of cinnamoninduced contact stomatitis. Compend Contin Educ Dent 2006; 27: 403-409.

6. Allen CM, Blozis G G. Oral mucosal reactions to cinnamon-flavored chewing gum. J Am Dent Assoc 1988; 116: 664-667

7. Mihail R C.Oral leukoplakia caused by cinnamon food allergy. J Otolaryngol 1992: 21:366-367.

8. Westra W H, McMurray J S, Califano J et al. Squamous cell carcinoma of the tongue associated with cinnamon gum use: a case report. Head Neck 1998; 20: 430-433.

doi: 10.1038/sj.bdj.4814167 